\title{
História de Polímeros no Brasil
}

Ao completarmos o oitavo ano de publicação regular de "Polímeros: Ciência e Tecnologia", verificamos com satisfação que a nossa revista cumpre com sucesso o difícil papel de manter a qualidade científica e tecnológica dos trabalhos publicados, tendo ainda no ano de 1998 ampliado de seis para oito o número de artigos publicados por edição. A revista foi classificada na categoria "A" de publicações brasileiras da área de Engenharias, na recente avaliação realizada pela CAPES.

Este aprimoramento contínuo da revista é fruto da colaboração de toda a comunidade de polímeros, seja pelo envio de trabalhos de boa qualidade, veiculação de notícias e informes publicitários, matérias jornalísticas, entrevistas com personalidades, como também pela importante participação dos consultores no referenciamento da revista.

Ao se aproximar do final da última década, marcando a virada do milênio, o comitê editorial achou oportuno resgatar um pouco dos aspectos históricos da implantação da ciência e tecnologia de polímeros no Brasil, e para este fim convidou a pioneira Dra. Eloisa Biasotto Mano, Professora Eméritus do Instituto de Macromoléculas da UFRJ, para lançar uma matéria sobre o tema. A Prof ${ }^{a}$ Eloisa procurou reunir num documento uma série de dados cronológicos que permitem à comunidade atual resgatar os pormenores da História de Polímeros no Brasil. Este documento não esgota o assunto e nem tem esta pretensão, e o comitê editorial encoraja outros profissionais a participarem desta iniciativa enviando matérias e comentários para a revista, compartilhando assim o seu conhecimento histórico junto com a comunidade brasileira de polímeros.

Ao terminar o último número do ano de 1998, o comitê editorial da revista gostaria de externar os seus agradecimentos aos consultores da revista e desejar a todos os leitores que o ano novo seja repleto de alegria e grandes realizações. 